\title{
GRADUATE OF RIGA POLYTECHNIC INSTITUTE, ATHLETICS STATISTICIAN ANDRIS STAĢIS
}

\section{ËRIKA LANKA*}

University of Latvia

ALĪDA ZIGMUNDE

Riga Technical University

Summary. The article summarizes the achievements of Andris Stagis, a graduate of the Faculty of Civil Engineering of Riga Polytechnic Institute (RPI; 1968), in the profession of an engineer, as well as reveals his contribution to the history and statistics of Latvian sports, achievements in athletics and their promotion. This is the first study on the activities and life of engineer, officer of the Order of the Three Stars, Latvian champion in athletics and the author of sports history books, and journalist $A$. Stagiis. The aim of the research is to reveal the contribution of $A$. Stagis and the significance of his personality to Latvia using his and the authors' personal archives, documents of the State Archives of Latvia, and the collection of the National Library of Latvia.

Keywords: Andris Staǵis, athletics statistics, Riga Polytechnic Institute.

\section{Introduction}

Andris Staǵis, a graduate of RPI Faculty of Civil Engineering, is one of those personalities whose name is inextricably linked with RPI, Latvian sports life, and events in the 20th and 21st centuries. He is the pioneer of Latvian athletics statistics, thus making an invaluable contribution to Latvia; he set the foundations of the history of athletics, wrote several books on the history of Latvian athletics, created a system for researching sports achievements, as well as experienced great moments in sports and is a Latvian patriot. The authors of the article focus on those areas of life of RPI graduate Andris Stagis in which his contribution has been significant and will remain in the future.

* Corresponding author.

E-mail: erika.lanka@edu.lu.lv 


\section{Childhood, School and Technical School Years}

Andris Staǵis was born on 3 August 1941 in Ropaži region. His mother Vera Staǵe (1910-2000) was born in Ropaži Parish and was a housewife for many years. His father Kārlis Staǵis (1914-1995) comes from Sēja Parish [1]; he graduated from Riga State Technical School (1935), studied at the Faculty of Mechanics of the University of Latvia (1941-1946) [2] and was a communications specialist all his life. A. Stagis' childhood memories are related to life near Riga - in Ropaži and Sēja. He spent the years of World War II (1941-1945) in his father's native home «Purgaili», Sejja Parish. He remembers the last year of the war- bombing, hiding in the basement, streams of refugees, etc. In 1946, the family moved to Riga, they walked from Sejja for two days to get to Riga. A. Stagiis' sister Maija Staǵe (b. 1943) was an infant at that time. The head of the family, K. Staǵis, started working as a telephone specialist and until 1973 A. Stagiis spent his childhood and youth in an apartment in the capital on Villandes Street. He spent the summers at his father's or mother's family home - in Sejja or in Ropaži. Together with the country-boys they had various competitions for who will write down the biggest number of passing cars, and had the «backyard» sports Olympiad. Sometimes, when others got tired, $A$. Stagiis played sports alone, measuring and recording his results [3]. During the school years, there were other sports activities in Riga, like hockey puck driving in Viesturdārzs together with peers.

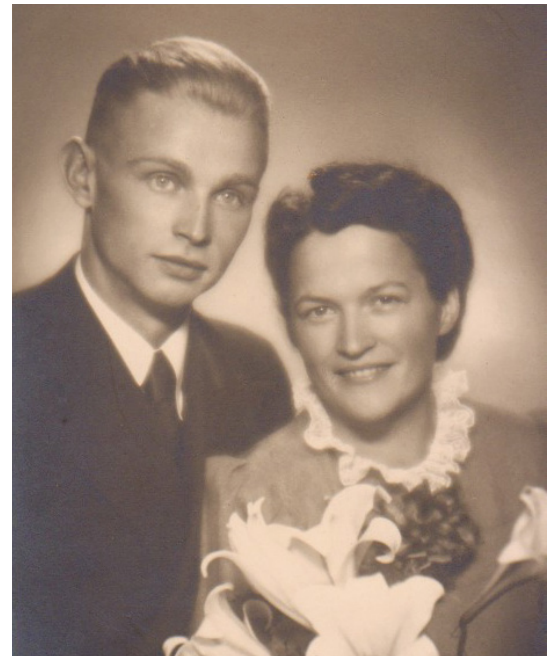

Figure 1. Parents of Andris Stagiis father Kārlis Staǵis (1914-1995), mother Vera Staǵe (1910-2000) on their wedding day (1940).

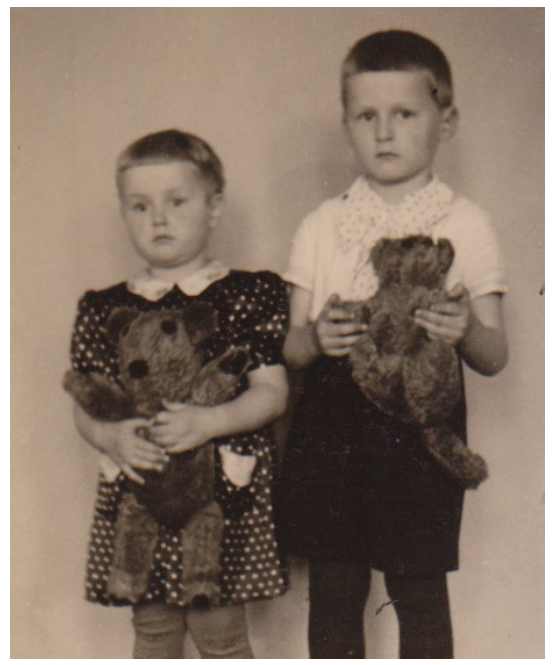

Figure 2. Maija (on the left) and Andris Staǵis (circa 1948). 
From 1948 to 1955, A. Stagiis studied at the 49th Seven-year School in Riga and during this time he took up sports seriously, dropping out of piano lessons started in primary school, got strong and healthy; A. Stagiis was was prone to illness in his childhood and adolescence. He was also not tall. At home, A. Staǵis and his sister had to perform various duties and help the family. The apartment had stove heating and he gladly chopped firewood.

For four years (1955-1959), A. Staǵis studied at Riga Industrial Polytechnicum (RIP) where he obtained the qualification of a mechanical technician in the specialty of factory equipment repair and assembly. While studying at the technical school, he obtained valuable profession as well as many friends who, getting together after 50 years they remember all the good things they have experienced when studying, working and relaxing.

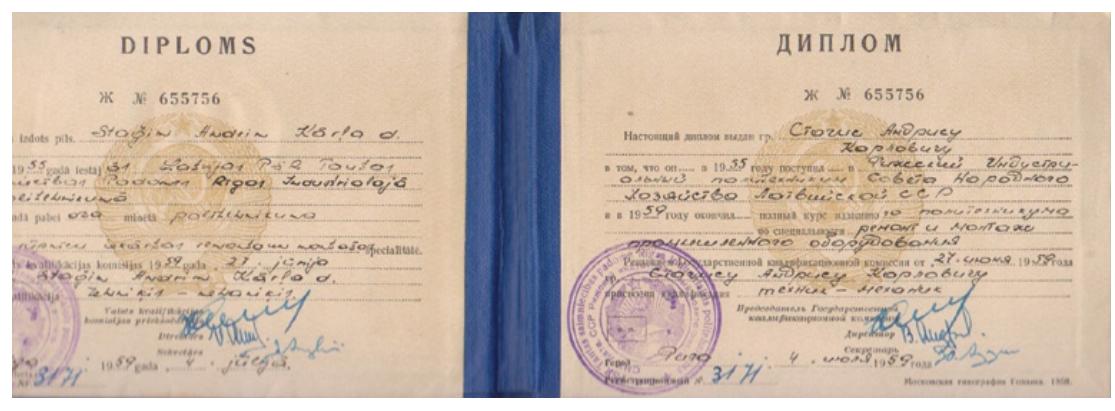

Figure 3.

Diploma of Andris Staǵis on graduation from RIP (1959).

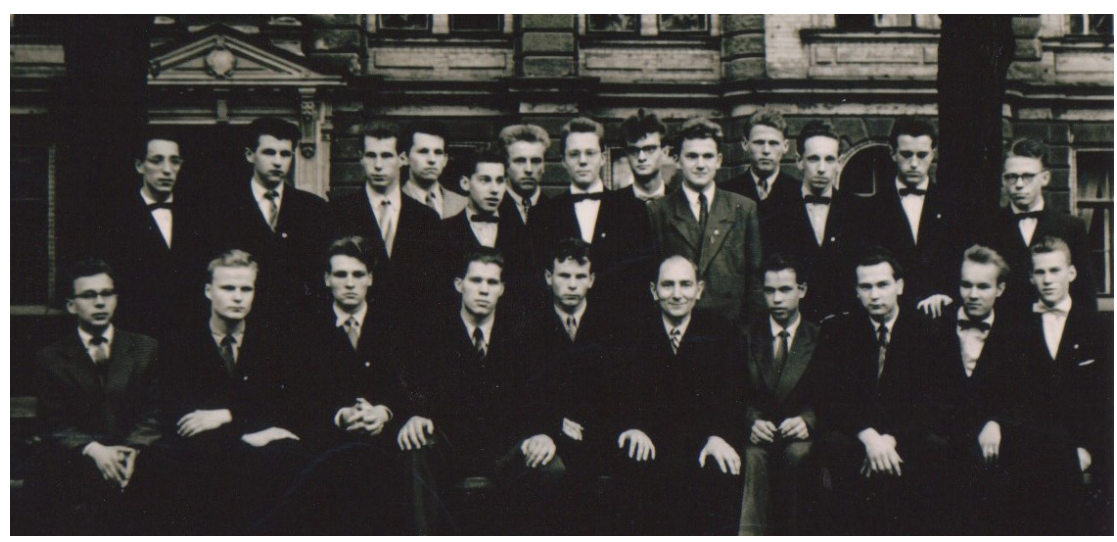

Figure 4. RIP graduates in the speciality of factory equipment repair and assembly (1959). Row 1 from the left: Leons Graholskis, Dainis Liepiņš, Edvīns Lapiņ̌s, Andris Meikališs, Juris Ivanovs, course teacher Eduards Veinbergs, unknown person, Ivars Arkls, Andrejs Ābols, and Vilnis Lazda. Row 2 from the left: Voldemārs Levanas, Arvīds Ozolants, Juris Leja, Jānis Bērzin̄š, Gunārs Lasmanis, Zigurds Braslis, Rihards Indriksons, Almārs Bergs, Edmunds Belohvoščiks, Andris Staǵis, Jānis Purmalis, Harijs Švanks, and Juris Prieditis. 


\section{Riga Polytechnic Institute and the Staǵi Family}

The life of A. Stagis and other family members of the Staǵi family is closely related to RPI. A. Stagiis began his studies in the specialty of sanitary engineering in the Faculty of Civil Engineering of RPI after serving in the army in the autumn of 1963, and in five and a half years, he obtained the qualification of a civil engineer-plumber. In the first two and a half years, he studied in the evening department - attended lectures, participated in seminars and performed laboratory work in the evening, while during the day working as a full-time repair locksmith, combining it all with sports.

While studying and playing sports, as well as representing RPI in student competitions, the management and teaching staff of the institute was very understanding and allowed to pass many exams and tests at later dates - favourable for A. Staǵis. He raised prestige of RPI and participated in competitions as its representative. His RPI diploma dates back to 27 December 1968, but his graduation took place in early 1969.

Figure 5. RPI Graduate Diploma of Andris Staǵis (1968).

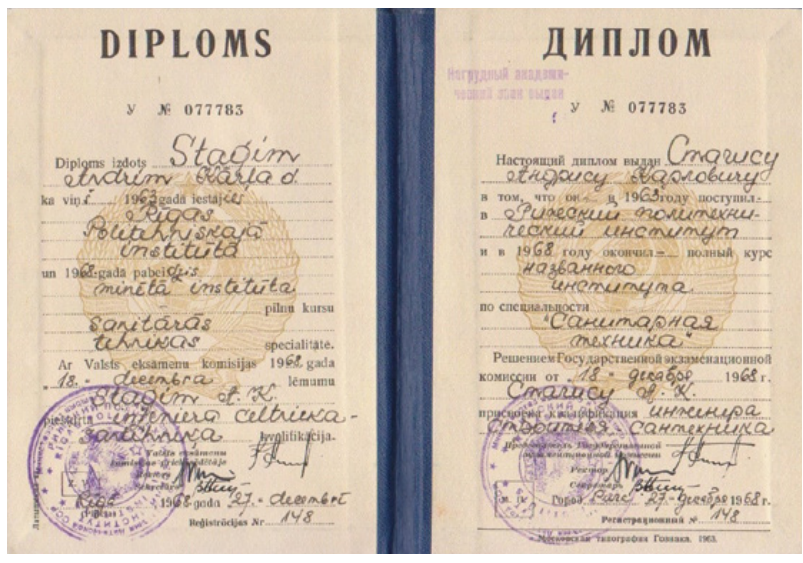

Figure 6. Graduates and lecturers of RPI Faculty of Civil Engineering (1968). Row 1 from the left: 5 th - Assistant Professor Emilija Moskovkina. Row 2: unknown person, Anna Karakečba, Ingrīda Jespere, unknown person, Dace Dzintare, unknown person. Row 3: Dainis Žube, unknown person, Mihails Aronovs, Andris Staǵis, Vilnis Brigmanis, Andris Krievs, and Ādolfs Señkāns.

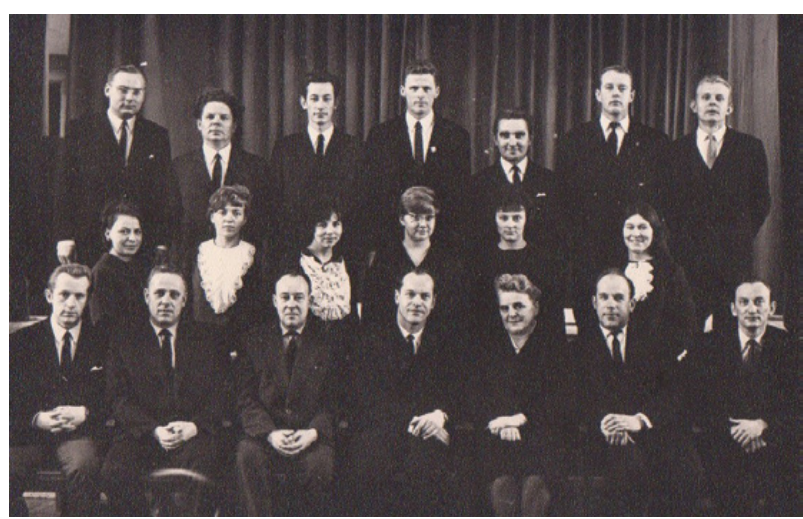


As already indicated, relatives of $A$. Stagiis are also related to RPI and its heir Riga Technical University (RTU). Sister Maija Staǵe (m. Šteina) graduated from RPI Faculty of Automation and Computer Technology (1966) and RTU Faculty of Transport and Mechanical Engineering (2009) in masters programme. Also her husband Uldis Šteins, brother-in-law of A. Stagiis, who was a long-term Chief Engineer of Riga Film Studio (1968-1978), Deputy Director (1978-1990), Director (1990-1998) and Head of RPI / RTU Folk Dance Ensemble «Vektors» is a graduate of RPI (1959). U. Šteins was the manager of «Vektors» for 55 years, until 2016, and Maija Šteina danced in it - during her study years and later in the middle generation and senior groups. Both children of Maija and Uldis also studied at RPI. Margita Staǵe (m. Sondore), the eldest daughter of A. Stagiis, graduated from RTU Faculty of Instrument Engineering and Automation (1993) and worked at RTU for many years - she was an assistant to Rector Ivars Knèts (1938-2019) and the senior quality systems specialist in the Academic Policy and Quality Department [5].

\section{Athlete's Life and Achievements in Sports}

Already during the school years, A. Stagiis actively played sports in the spacious yard of the house and in summer in the countryside. In his free time, he played basketball and volleyball with his peers and did sports in the athletics stadium. Thanks to physical activity he found his lifelong occupation.

In 1953, being a student, A. Stagiis turned to sports. The interest in athletics was also stimulated after seeing the film about the 1952 Olympic Games in Helsinki together with the farm boys. After that, they organized their Olympiad and prepared the necessary equipment themselves - they made a disc. Later, A. Stagiis made his own hammer out of lead [6]. While studying at the technical school, in 1957, he began to train regularly in athletics with coach Eduards Jakobsons (1914-1993).

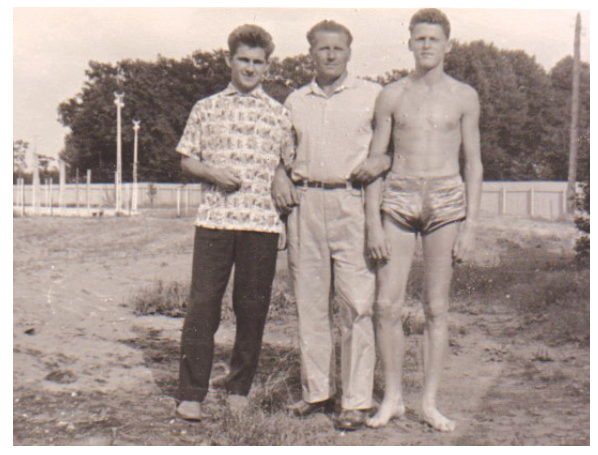

Figure 7. Athletes with coach Eduards Jakobsons (in the middle). From the left: Guntis Osvalds, Eduards Jakobsons, and Andris Stagiis (circa 1960). 
Figure 8. Andris Stagiis throws a disc in the Baltic Youth Games in Riga (1960).

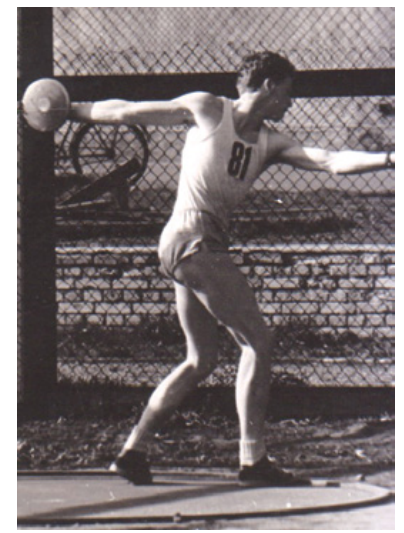

He achieved good results - in 1960 A. Staǵis set a Latvian record in throwing a $6 \mathrm{~kg}$ hammer for young people $(53.11 \mathrm{~m})$ in the competition of members of the youth teams of the Baltic republics and the Soviet Socialist Republic of Belarus (19 years old and younger). In this competition, he also won the $1.5 \mathrm{~kg}$ discus throw (48.12 $\mathrm{m}$ ) [7]. After enlisting in the Soviet Army, the athlete continued training in Kaliningrad, Russia, where he served until demobilization in 1963. Good physical fitness helped in military service and also in sports competitions. A. Staǵis had also grown considerably - his height was 1.89 meters and he was strong and healthy. In 1962, at the competition in Orekhovo-Zuyevo, Moscow region, he became the junior champion of the Russian Soviet Federative Socialist Republic in triple jump (13.98 m).

Figure 9. Serving in the army in Kaliningrad A. Staǵis trains in hammer throwing (1962).

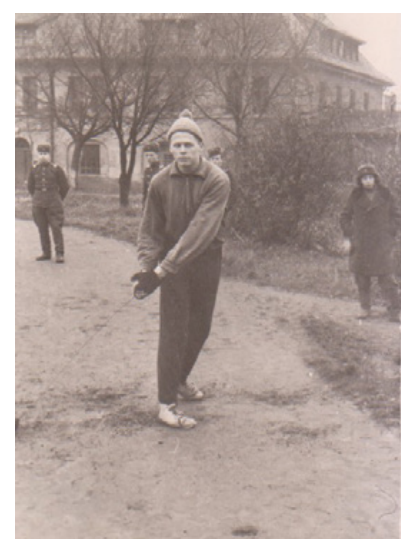

Since 1960, A. Staǵis has been an athlete of the Latvian national team. During his studies (1964-1968), he was one of the best athletes in RPI in several athletics disciplines - 100, 200 and 400 meters run, 110 meters and 200 meters hurdles, high jump, card jump, long jump, disc and 
spear throwing, shot pot, decathlon, as well as hammer throwing and triple jump $[8,9,10,11,12]$. In the last two disciplines, he was twice the champion of Latvian student spartakiads $(1965,1966)$, representing RPI. A. Staǵis' result in triple jump (15.62 m) in 1968 was an RPI record for a long time. The athlete was four times the Latvian vice-champion in hammer throwing, long jump and triple jump (1964-1969). Until 1970, he was in the Latvian athletics team. In the 1980s-1990s he played hockey. He was a goalkeeper of the amateur hockey team of the Riga Wagon Building Factory.

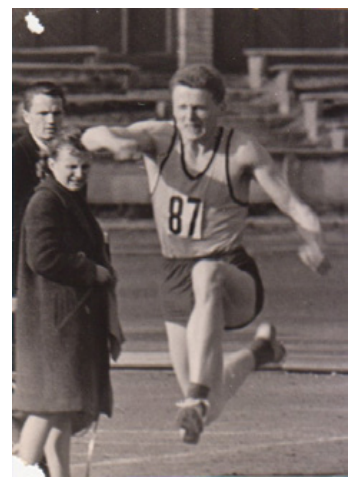

Figure 10. Start of triathlon in Latvian students' spartakiad (mid-1960s). From the left: first - Ivars Knèts, third - Andris Staǵis.
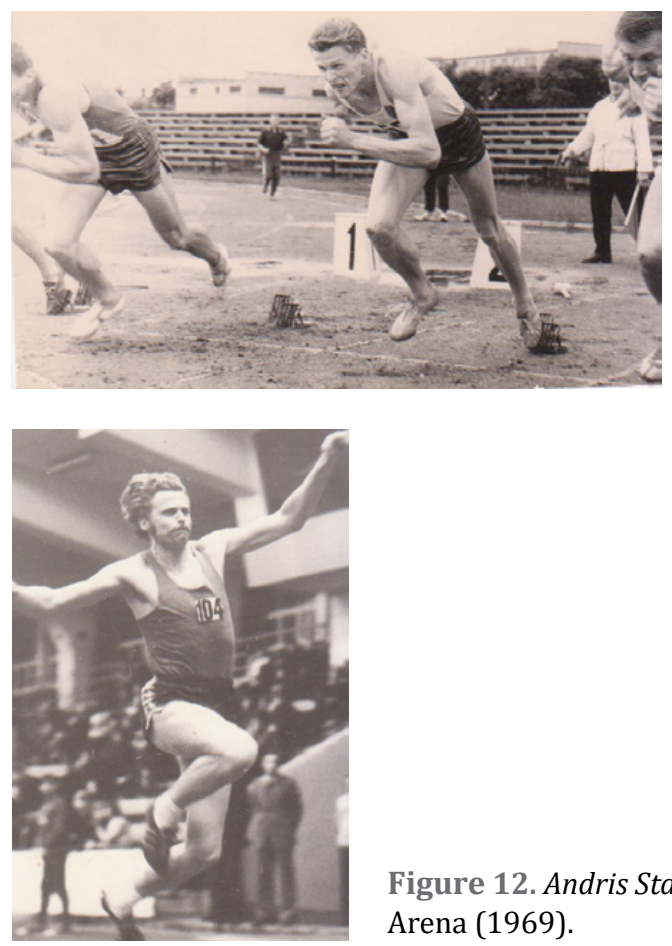
Arena (1969).
Figure 11. A. Staǵis starts in the $100 \mathrm{~m}$ race in the Baltic Games in Panevezys, Lithuania (1966).

Figure 12. Andris Stagiis in long jump in Riga Sports 


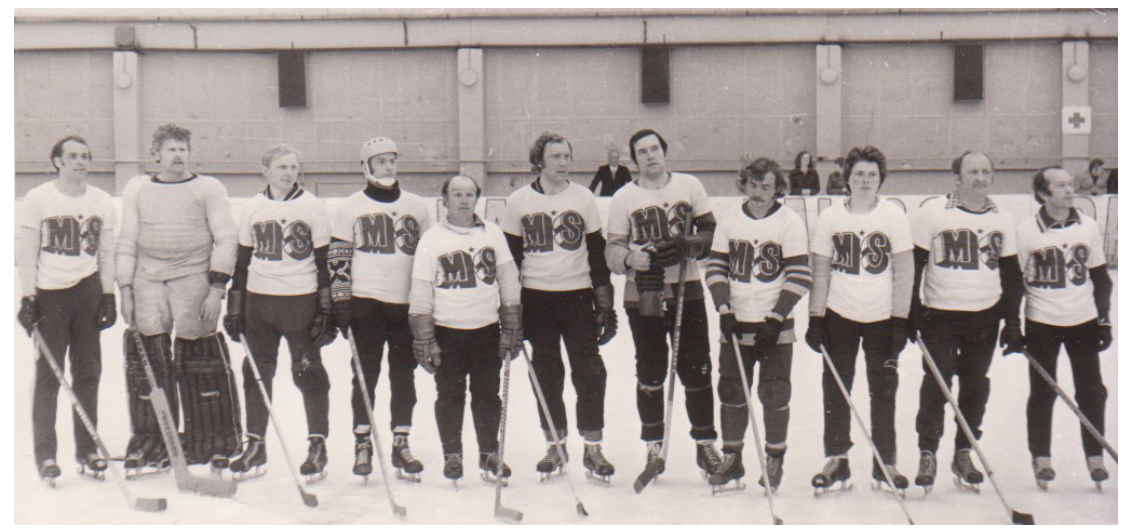

Figure 13. Riga Wagon Building Factory amateur hockey team. Second from the left: Andris Staǵis (1980s).

After the dynamic activities of the athlete, the connection with sports remains. Since 1984, A. Staǵis has also been an informant referee in athletics competitions. He has been in this position 560 (!) times, until April 2020 [13]. When he was invited to be the competition commentator, A. Staǵis carefully prepared for that so that the comments about the athletes' achievements and places in the world or in Latvia were accurate.

Figure 14. Athlete competition informant referee at his workplace (early 21st century).

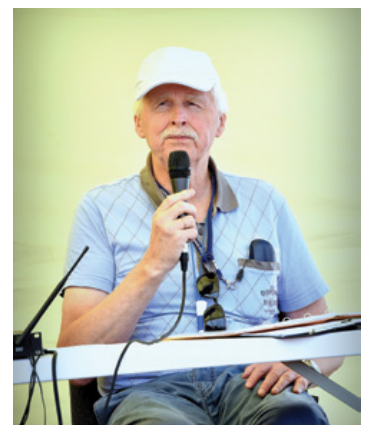

Figure 15. Andris Stagiis after the starts and wins in the veteran athletics competition at the «Daugava» Stadium in Riga (around 2010).

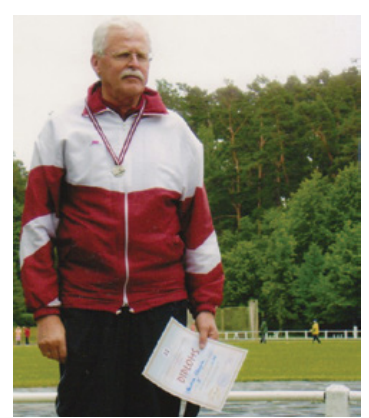


Sport has occupied an important place in the life of $A$. Stagis for the seventh decade. In recent decades, activities in the athletics team of veterans have played an important role in his life. In such competitions, in addition to good results, it is satisfying to prove oneself and to enjoy being together with like-minded people. Numerous interesting competitions and games have been experienced together with youth friends and competitors not only in Latvia. A. Stagis has also proved himself internationally - in 2008 he won a bronze medal in hammer throw $(38.52 \mathrm{~m})$ at the European Masters Games in Malmö, Sweden. The games were also special for the athlete because his wife Gunta Staǵe also returned home with a bronze medal won in discus throwing (20.98 m) [14].

\section{Research of Sports History, Sports Journalism and Recognition}

A. Staǵis has achieved success in various sports disciplines. This has definitely helped him in compiling sports history and athletics statistics.

Since 1963, A. Stagis has been engaged in athletics statistics, he was encouraged to do so by a member of decathlon, a graduate of RPI (1961) and later the rector of RTU, academician Ivars Knets (1938-2019). In the beginning it was collecting and summarizing sports results, recording and systematizing the facts of sports history of RPI, later - on a national scale. It became a hobby for a lifetime and A. Staǵis is rightly called a Latvian athletics statistician and historian. In 1971, A. Stagiis became a member of the International Association of Track and Field Statisticians (ATFS), which has about 300 members from all over the world [6].

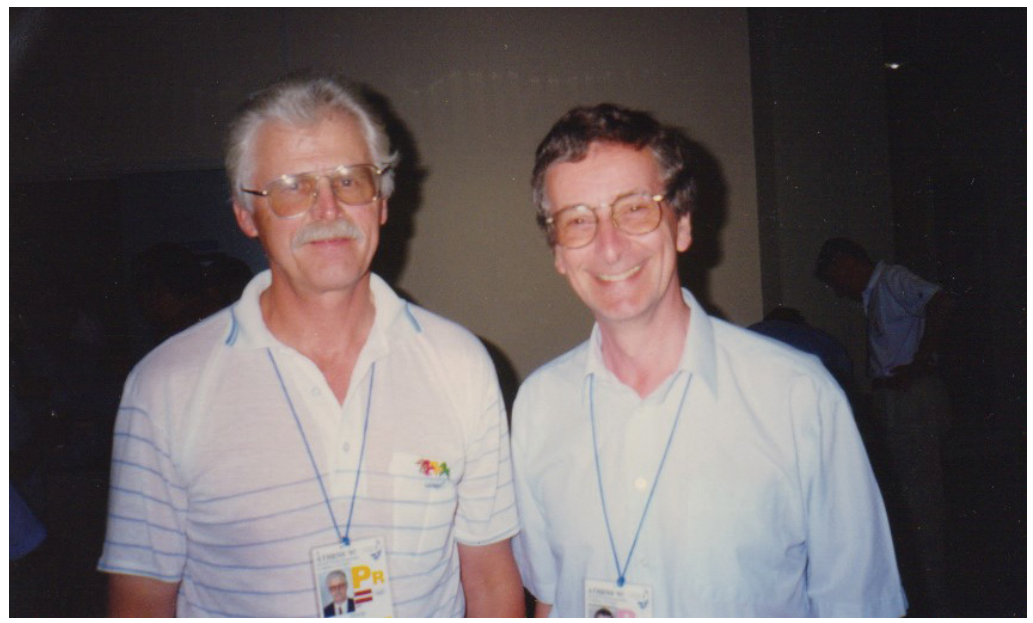

Figure 16. Together with the world's leading athletics statistician Peter Mathews from Great Britain (early 21st century). 
Figure 17. A. Staǵis at home at the filing cabinet and computer -the workplace of a statistician (beginning of the 21st century).

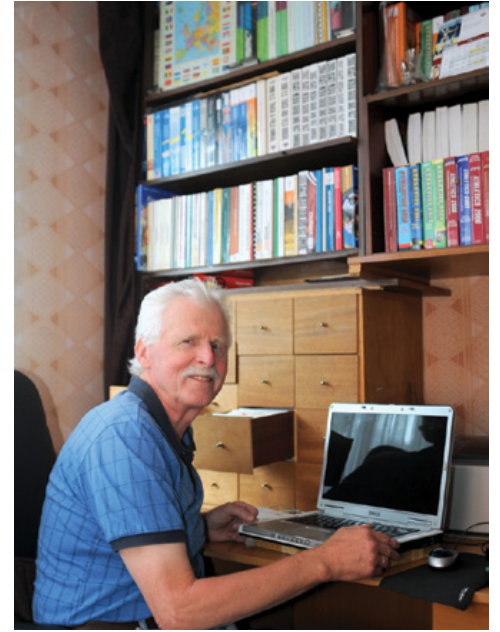

The work of statisticians has changed dramatically over the years. A. Stagis once contacted with the help of letters and provided information to foreign statisticians about the results in the Union of Soviet Socialist Republics. He himself had folders with newspaper and magazine clippings [15], notebooks with notes and data from the press, as well as a "cabinet of numbers», which contained cards with data on almost every important newspaper and magazine clippings athletics event in Latvia and in the world [6]. Nowadays, computers make the job of compiling the results much easier, but the file or «athletics' Daina cabinet», as journalists call it, is still performing its function.

Figure 18.

Journalists at the World Championships in Athens in the workplace of journalists (1997). From the left: Andris Staǵis, Egils Jurisons.

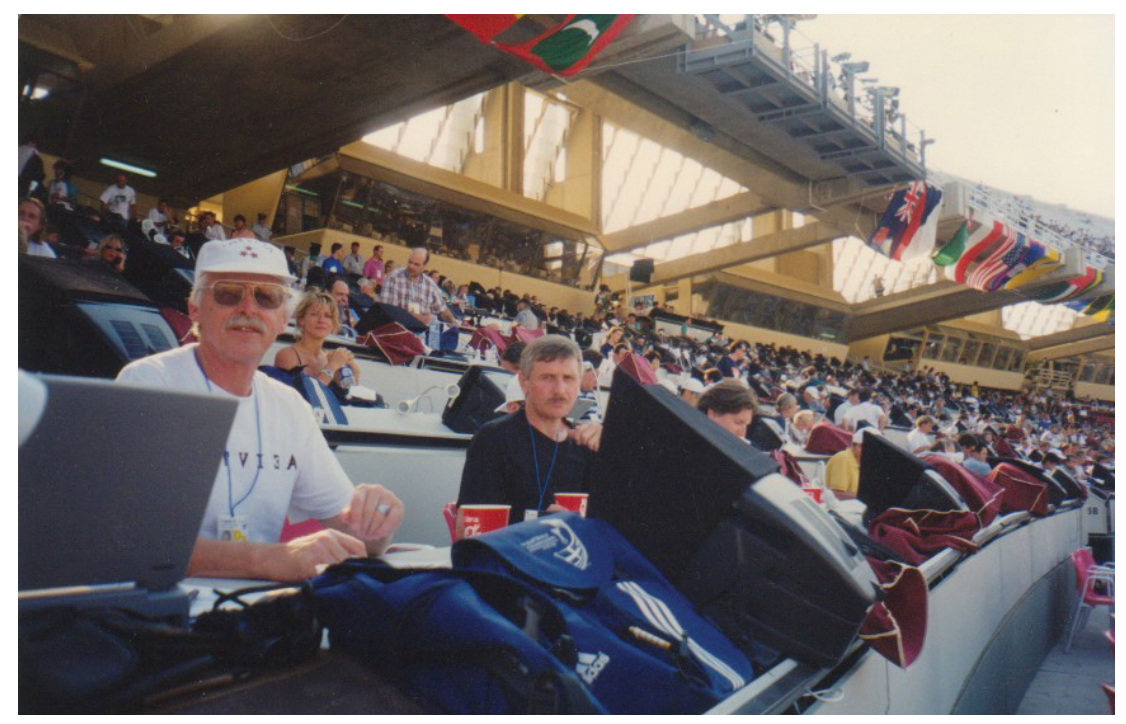




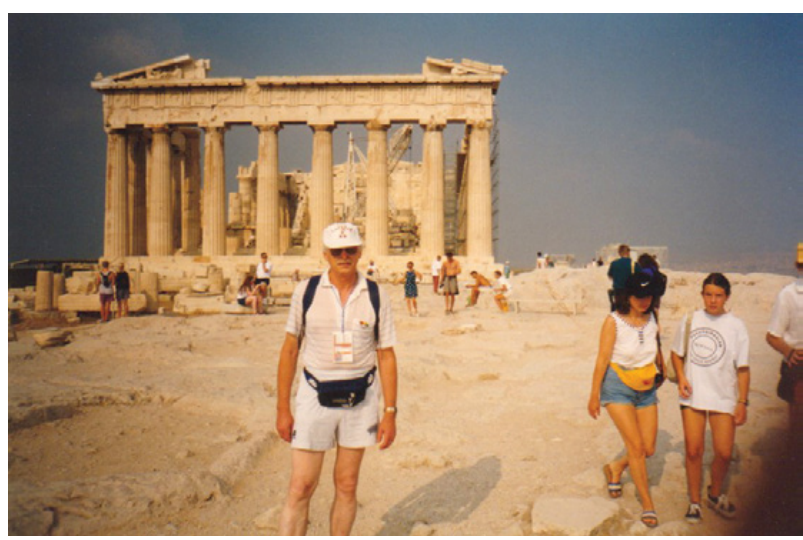

Figure 19.

Excursion during the World Championships in Athens - Acropolis of Athens (1997).

As a journalist, A. Staǵis has participated in nine world athletics championships (1995-2009) and six European championships (19942015), reflecting the impressions gained in person in the Latvian sports press. He is having excellent professional relationship and is exchanging information with many Latvian professional journalists writing about athletics - Egils Jurisons, Jānis Matulis, Armands Puče, Anatolijs Kreipāns, and others.

The highlight of his journalist's life is the 1995 World Athletics Championships in Gothenburg, Sweden, where he saw two phenomenal world triathlon records set: Jonathan Edwards, UK, jumped 18.29 m [16] and Inesa Kraveca (Інеса Миколаївна Кравець, Ukraine) - 15.50 m [17]. Both records are still unbeaten even after 25 years. A. Staǵis was a special correspondent of newspapers at the competitions [18], because his professionalism could always be relied on. In his turn, A. Stagiis not only performed the duties of a sports journalist professionally, he was also an eyewitness to sports results.

As a result of several decades of diligent work, A. Stagiis has published many articles and several fact-rich books: «Latvijas vieglatlètika 100 gados» («Latvian Athletics in 100 Years») (1996), «Latvijas vieglatlēti olimpiskajos 100 gados» («Latvian Athletics in 100 Olympic Years») (1998), «Latvijas vieglatlētika 100 gados» («Latvian Athletics in 100 Years») (2000), «Latvijas sports» («Latvian Sports»; Latvijas mazā enciklopēdija/ Latvian Small Encyclopaedia, 2008), «Šķēpa karalis Jānis» («King of Javelin Jānis») (2009), «Kārtslēkšana pasaulē un Latvijā» («Card Jumping in the World and in Latvia») (2011), «Latvijas barjerskrējēji: no Alslēbena lìdz Olijaram» («Latvian Hurdles: from Alslēbens to Olijars») (2013), «Latvijas vieglatlètikas vēsture: 1897-1944» («History of Latvian Athletics: 1897- 1944») (2016), «Latvijas vieglatlētikas vēsture: 19441991» («History of Latvian Athletics: 1944-1991») (2017), «Latvijas vieglatlētikas vēsture: 1992-2018» («History of Latvian Athletics: 
1992-2018») (2018), «Šk̦ēpiem mirdzot: Latvijas šḳēpmešanas vēsture 1901-2017» («Shining Javelins: History of Latvian Javelin Throwing 1901-2017») (2019). He has also compiled the annual Latvian Yearbook of Athletics (1991-2009).

A. Staǵis has established friendly and collegial relations with athletes and journalists. He always has time to search for accurate data and to help find out the results. Collegial cooperation and common interests on the issues of Latvian sports history and its documentation unite A. Stagis with former sports wrestling member and RPI graduate (1972) Mārtiñš Stabiňs, who helped him find photographs of books published a few years ago about Latvian hurdlers and the beginnings of Latvian athletics history.

Figure 20. Cover of the book «Latvijas barjerskrējēji: no Alslēbena līdz Olijaram» (2013) compiled by A. Staǵis.

\section{Figure 21.}

Presentation of Andris Stagis book «Latvijas vieglatlētikas vēsture: 1897-1944» in bookstore «Jumava» in Riga, 73 Dzirnavu Street (2016). From the left: I. Knèts, A. Staǵis.
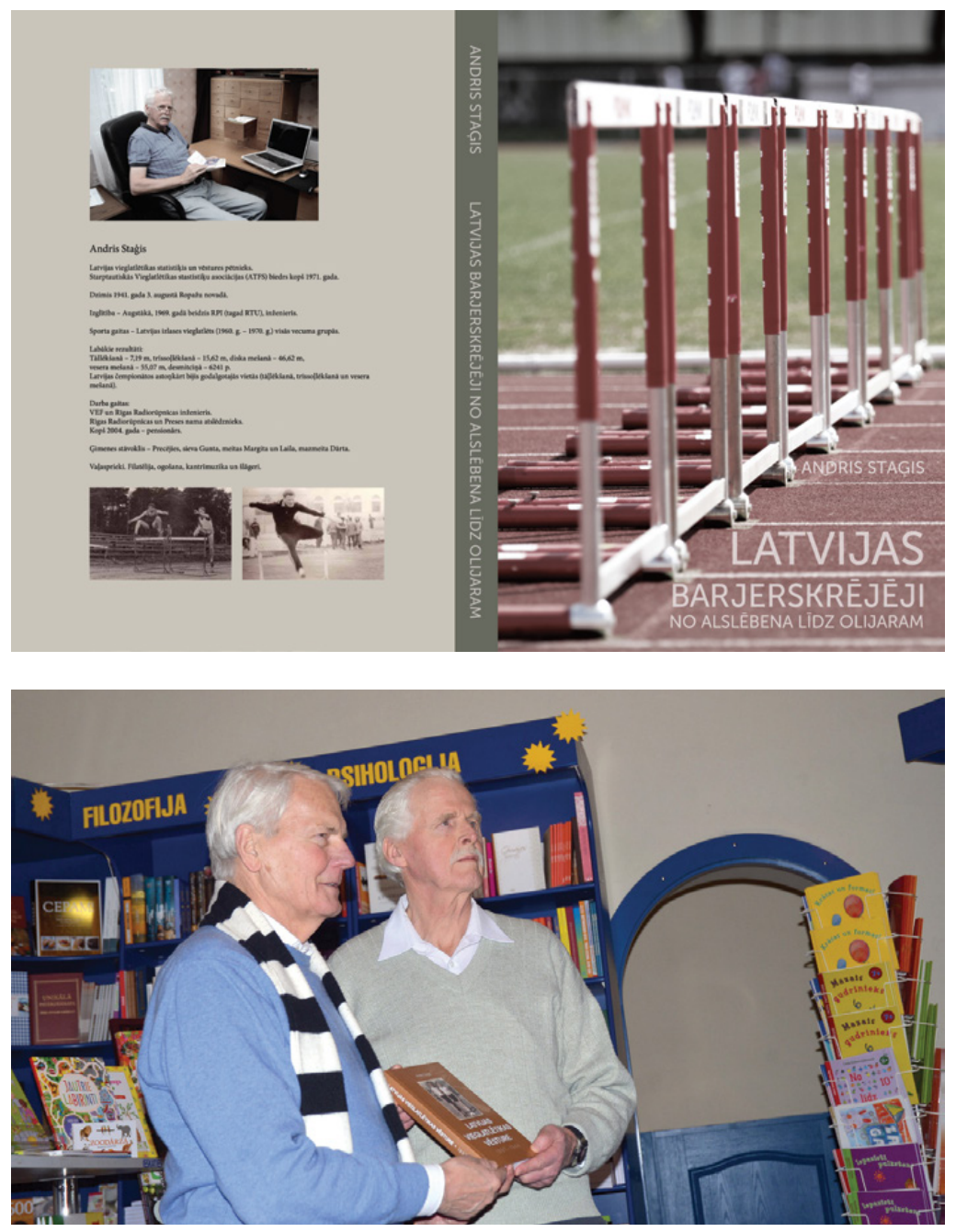


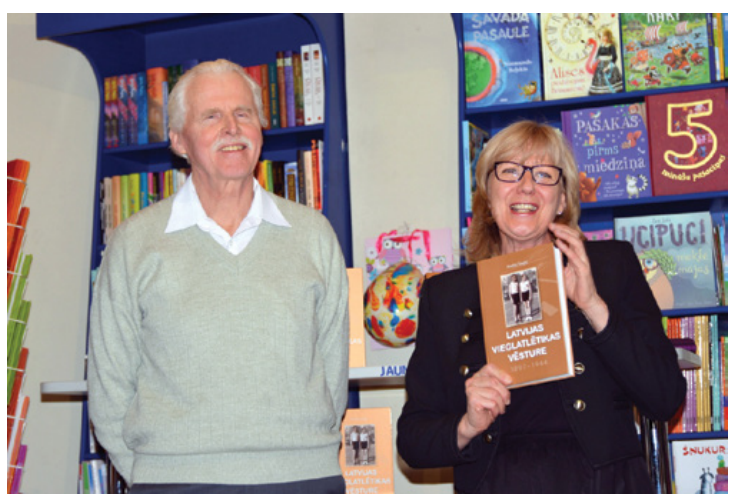

Figure 22. Presentation of Andris Staǵis' book «Latvijas vieglatlētikas vēsture: 1897-1944» in bookstore «Jumava» in Riga, 73 Dzirnavu Street (2016). From the left: Andris Staǵis, editor Zenta Valtere.

The unique work of A. Staǵis in preserving, systematizing, documenting and promoting the history of sports has been highly appreciated in Latvia for several decades. During the celebration of the centenary of Latvian athletics in 1998 he was awarded a Certificate of Recognition from the Cabinet of Ministers of the Republic of Latvia, and in 2018 - with the Order of the Three Stars of the Fifth Class [19], as well as the annual «Sporta balvu par mūža ieguldïjumu» («Sports Award for Lifetime Contribution» of the Latvian Athletics Union. In 2016, he received the European Athletics Association Award for Novelty.
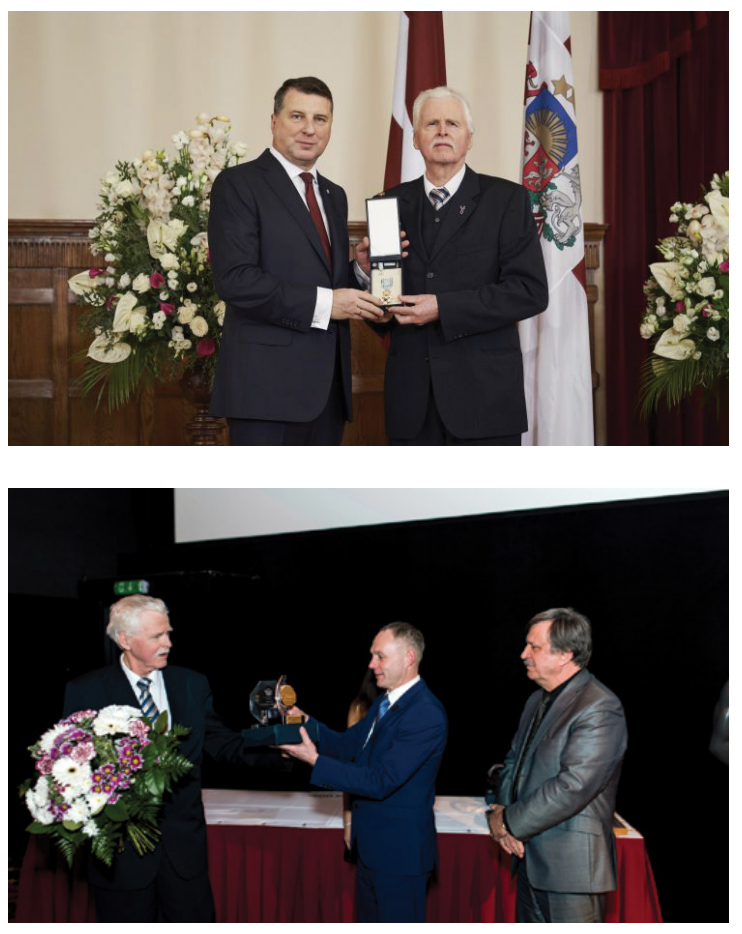

Figure 23. President Raimonds Vējonis (first from the left) presents to A. Stagis the Order of the Three Stars of the Fifth Class (17.11.2018).

Figure 24. Andris Staǵis (first from the left) receives the Latvian Athletics Union's annual «Sporta balva par mūža ieguldïjumu» («Sports Award for Lifetime Achievement») (2018). 
A. Staǵis still has a lot of different ideas, a huge field of work in systematizing and preserving the facts of sports history and his great love of his life - athletics - will give him and us all beautiful moments that make us proud of Latvian athletes and their achievements. Andris Staǵis practically has no moments of leisure, because he always has to be in his «position».

\section{Professional Work}

A. Stagiis is best known for his hobbies, but he has also done nonsports jobs for many years. From 1959 to 1960, after graduating from the technical school, he was a locksmith at the bicycle factory «Sarkana Zvaigzne» («Red Star»). This was followed by service in the Soviet Army, from which he returned in 1963. He used the professional knowledge of a repair locksmith in his new workplace - factory «Santehnikis» («Plumber») (1963-1965), combining studies with work. The locksmith's job was a good practice in the workplace related to the specialization of the future engineer. From 1969 to 1973, after studies at RPI, A. Staǵis was an engineer at the State Electrical Engineering Factory (VEF). From 1974 to 1985, he was an engineer and Head of the Ventilation Bureau of the Riga Radio Factory [15], then a locksmith in the factory's Radio Box Shop, for a short time he was the factory's deputy chief energy engineer (1992-1993).

Figure 25.

Tinsmith's work on the roof of the «Press House» (late 20th century).

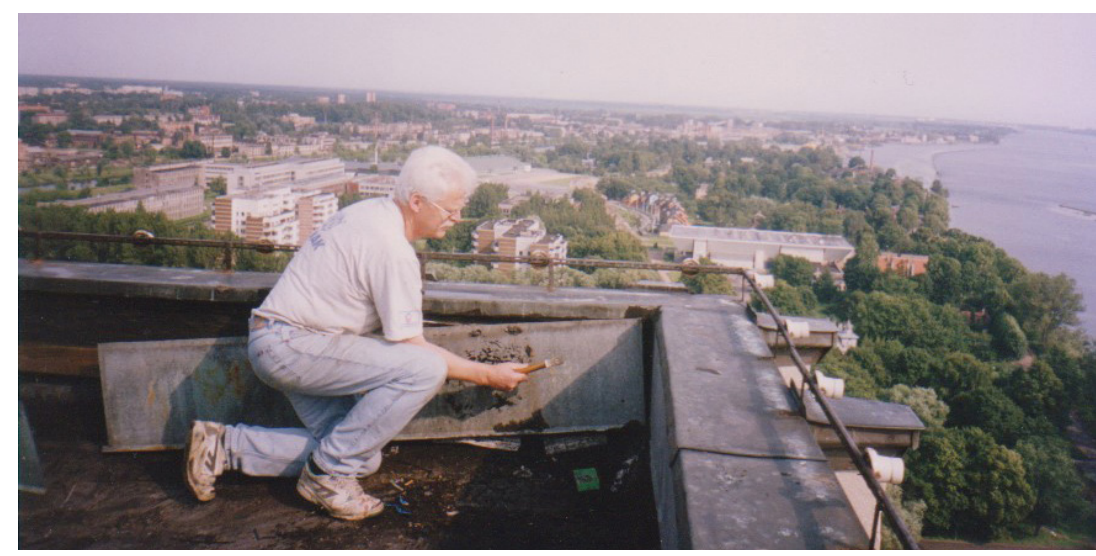

A. Staǵis' last job was at the «Preses nams» («Press House») printing house, where he worked as a locksmith for the repair of ventilation and air conditioning equipment from 1993 to 2004, when he retired [13]. 


\section{Strong Support - Family}

Success in sports for A. Stagis is inextricably linked to happiness in private life. While playing sports and training, he met a nice training partner - Gunta Muceniece. While still a student, A. Staǵis married (in 1966) and has been with his wife for more than 50 years. His wife $G$. Staǵe has also achieved good results in sports not only in her youth, and the range of the received medals is quite large. She is still a sportswoman and ranks among the best not only in Latvian sports veterans' competitions in shot put, disc, hammer and spear throwing [20] but is also in sports veterans' competitions held abroad. Loving family is very supportive and understanding in A. Staǵis' intensive pace of daily work, which has not decreased after the retirement. Festive times are, of course, spent together. His wife Gunta Staǵe, daughters Margita Sondore and Laila Staǵe, and granddaughter Dārta Sondore ensure that there is a loving and bright atmosphere in the family after intensive work, which is a source of energy for big and small deads.

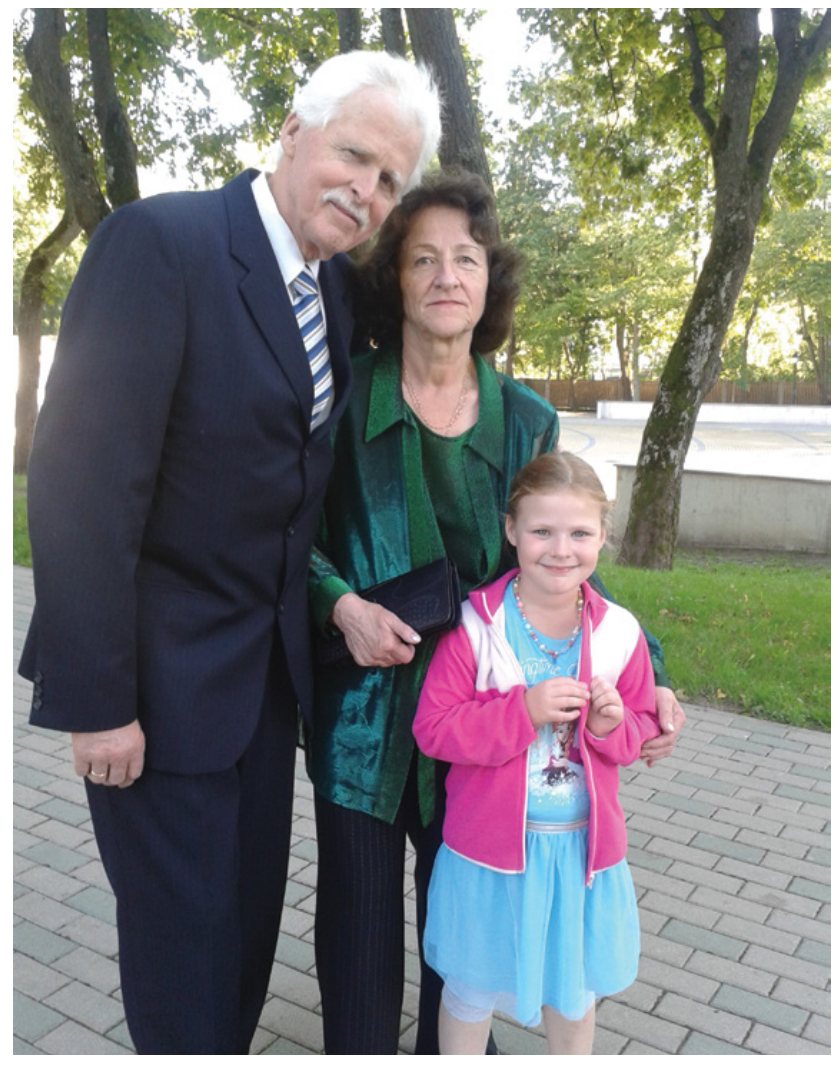

Figure 26. At the golden wedding celebrations in culture palace «Ziemellblāzma» with his wife Gunta Staǵe and granddaughter Dārta Sondore (2016). 


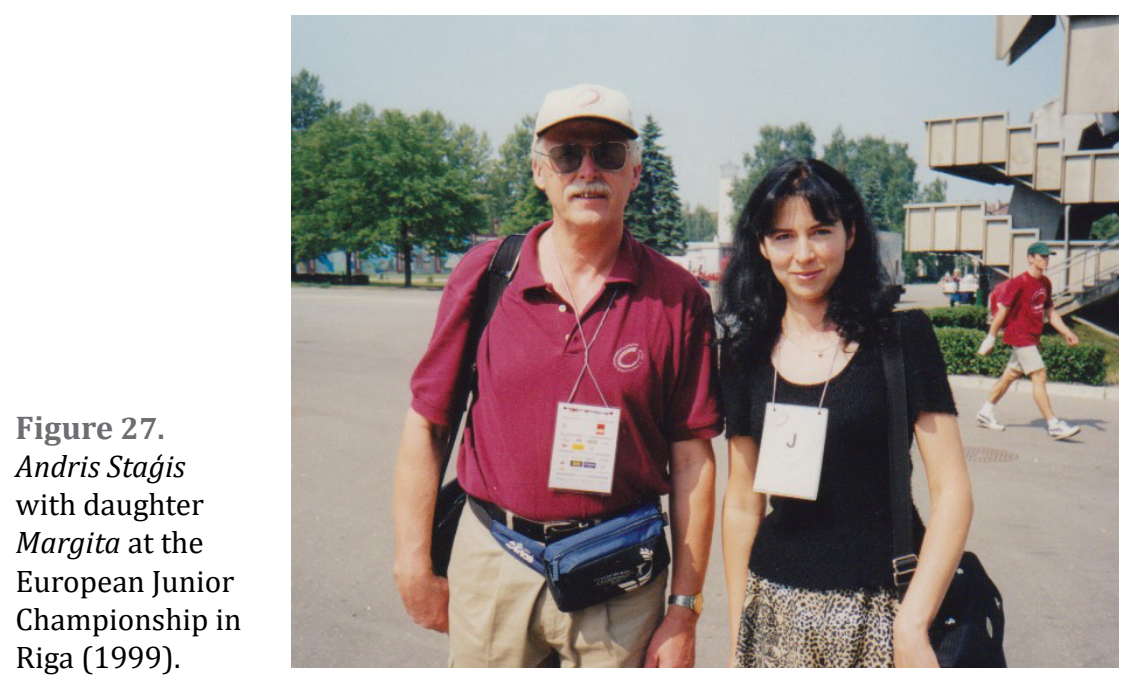

A. Staǵis has also managed to attract his eldest daughter Margita to one of his activities - the duties of an informant. For example, in 1999, she was a competition informant at the European Junior Championship in Riga.

Andris Staǵis also finds time for other hobbies - berry picking, philately, country and hit music recordings, and collecting books about the Olympic Games. For some time he also started collecting Olympic badges [3].

He still fixes everything at home. Work life and study time at RPI prepared him for various jobs. A. Stagiis' field of work is infinitely wide, but he has been able to organize his every working day from morning to evening by minutes. And he has enough time for sports and other hobbies.

\section{Conclusions}

Riga Technical University, the heir of RPI's traditions and activities, has many outstanding graduates who are known for their high sports achievements. One of them is RPI graduate, officer of the Order of the Three Stars, one of the pioneers of Latvian sports statistics, author of sports history books, athlete, journalist, and engineer A. Stagiis, of whom the university is really proud. In his youth, he raised the prestige of RPI by winning many medals at the Latvian Championships, confirming that his alma mater is a university that has rich sports traditions and outstanding athletes. A. Staǵis was a Latvian national team athlete (1960-1970) had best results in long jump (7.19 m), triple jump 
(15.62 $\mathrm{m})$, disc throwing (46.62 $\mathrm{m})$, hammer throwing $(55.07 \mathrm{~m})$, and decathlon (6241 points) [6]. We can be proud of A. Stagis' performance in veteran sports as well, especially the bronze medal won in the hammer throwing at the European Athletics Veterans Games in 2008.

The books written by A. Stagis and compiled statistics are important in the history of sports. Decades have been dedicated to this work and it has always been a selfless work for the present and the future, which is appreciated and respected in Latvia and in the world. The name of $A$. Staǵis is known to everyone who is interested in sports. Being a versatile personality, A. Stagis is also satisfied with the work done, because he has achieved two main goals - he has been a member of the Latvian national team and has obtained higher education [6].

RPI gave A. Stagis wings and they took him really high - albeit in a field not related to the work of an engineer. But the awards of the Republic of Latvia are a testament to the fact that this work is of a lasting value that will remain for future generations and promote the image of Latvia far in the world.

\section{REFERENCES}

[1] Kārḷa Staǵa Latvijas Republikas pase. Latvijas Nacionālā arhīva Latvijas Valsts vēstures arhīvs (turpmāk - LNA LVVA) 2996. f., 17. apr., 40196 . l.

[2] Latvijas Universitātes studenta Kārḷa Staǵa personāllieta. LNA LVVA 7427. f., 2. apr., 635. l.

[3] Kundziṇš, A. Uz jautājumu «Kā kḷūt par sporta statistiḳi?» atbild Andris Staǵis. Pionieris, 1980. gada 5. februāris, Nr. 11, 2. lpp.

[4] Augstākās tehniskās izglītības vēsture Latvijā. Rìgas Tehniskā universitāte 1991-2008. 4. dalı. Rìga: RTU, 2011, 82. lpp.

[5] Augstākās tehniskās izglītības vēsture Latvijā. 5. daḷa. Rīga: RTU, 2017, 623. lpp.

[6] Bērziņš-Soms, J. Andra Staǵa skaitl̦u skapis. Sports, 2012. gada 14. septembris, Nr. 17/18, 54.-57. lpp.

[7] Kad tēvus nomaina dēli... Padomju Jaunatne, 1960. gada 10. jūnijs, Nr. 113, 3. lpp.

[8] Pieci labākie RPI vieglatlēti 1964. gadā. Jaunais Inženieris, 1965. gada 18. janvāris, Nr. 1, 4. lpp.

[9] RPI labākie vieglatlēti 1965. gadā. Jaunais Inženieris, 1966. gada 17. janvāris, Nr. 1, 4. lpp.

[10] RPI labākie vieglatlēti 1966. gadā. Jaunais Inženieris, 1967. gada 30. janvāris, Nr. 3, 3. lpp.

[11] Labākie RPI vieglatēti 1967. gadā. Jaunais Inženieris, 1968. gada 26. janvāris, Nr. 3, 4. lpp. 
[12] Liepiṇš, K. Labākie vieglatlēti. Jaunais Inženieris, 1969. gada 8. maijs, Nr. 31, 4. lpp.

[13] Ėrikas Lankas intervija ar Andri Staǵi 2020. gada 22. marts. Ē. Lankas personīgais arhīvs.

[14] Latvijas vieglatlēti-veterāni startē Eiropas sporta veterānu spēlēs [tiešsaiste]. https://lat-athletics.lv/latvijas-vieglatleti-veterani-starteeiropas-sporta-veteranu-speles/[skatīts: 2020. gada 2. aprīlī].

[15] Jurisons, E. Uzdot jautājumu - tas nav maz. Liesma, 1976. gada 1. decembris, Nr. 12, 22. lpp.

[16] Jonathan Edwards [tiešsaiste]. https://www.worldathletics.org/athletes/ great-britain-ni/jonathan-edwards-773 [skatīts: 2020. gada 31. martā].

[17] Inessa Kravets [tiešsaiste]. https://www.worldathletics.org/athletes/ ukraine/inessa-kravets-61002 [skatīts: 2020. gada 31. martā].

[18] Staǵis, A. Mūsu desmitcīnnnieki Tallinā divreiz otrie. Diena, 1994. gada 4. jūlijs, Nr. 152, 7. lpp.

[19] Andris Staǵis saṇems Triju Zvaigžņu ordeni, Biruta Grantiṇa un Mārīte Lūse - Atzinības krustu [tiešsaiste]. https://athletics.lv/lv/article/3135/ andris-stagis-sanems-triju-zvaigznu-ordeni-biruta-grantina-un-marite-luseatzinibas-krustu [skatīts: 2020. gada 3. aprīīi].

[20] Gunta Staǵe [tiešsaiste]. https://athletics.lv/lv/person/2123 [skatīts: 2020. gada 4. aprīlī].

\section{SOURCES OF ILLUSTRATIONS}

Figures 1-13, 15-27. A. Staǵa personīgais arhīvs.

Figure 14. Jura Bērzinga personīgais arhīvs.

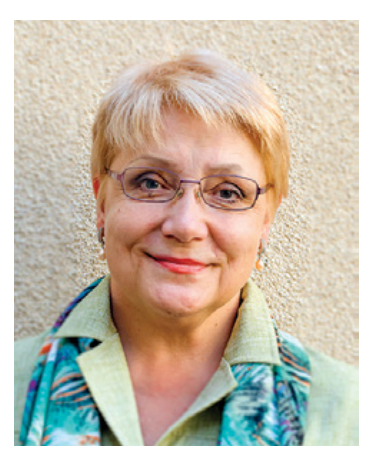

ĒRIKA LANKA, Mg. paed., Mg. phil., graduated from University of Latvia. From 1984, she was a lecturer at the Faculty of Education of University of Latvia, from 2008 she has been Director of one of the Programmes at the Centre of Adult Pedagogical Education of the Faculty of Education, Psychology and Art. She had participated as an expert in a lot of Latvian and foreign research projects, at the same time working as a teacher at schools. Her main academic interests include the philosophy of education, ethics, axiology, values and codex of teacher, history of pedagogy in Latvia and in Europe. She is a co-author of two monographies and the author of more than 35 publications.

Address: Imantas 7. linija, 1, Rigga, LV 1083, Latvia

Phone: +37129264829

E-mail: erika.lanka@edu.lu.lv,erikalanka@inbox.lv 


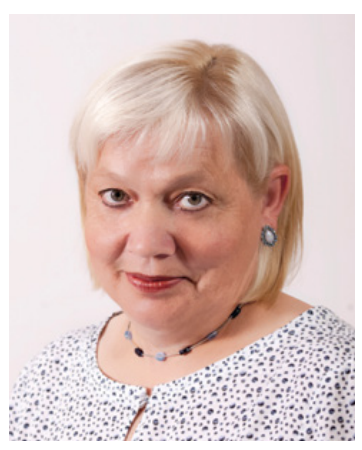

ALİDA ZIGMUNDE, Mg. phil., Dr. paed., has been a Specialist with the Museum of Riga Technical University since 1989. From 2007 to 2015, she was a Senior Researcher. She is currently a Professor with the Institute for Humanities and Head of the Department for Historic Research and Scientific Publications of the RTU Research Centre for Engineering History. Her main academic interests include the history of pedagogy in Europe, the history of educational institutions and of private schools, and the history of pedagogy of universities, of engineering sciences and universities.

Address: 1 Kronvalda bulvāris, Room 203, Riga, LV-1010, Latvia

Phone: +371 29869642

E-mail:alida.zigmunde@rtu.lv

Ērika Lanka, Alīda Zigmunde

\section{Rīgas Politehniskā institūta absolvents, vieglatlētikas statistiḳis Andris Staǵis}

Rakstā apkopots Rīgas Politehniskā institūta (RPI) Celtniecības fakultātes absolventa (1968) Andra Staǵa veikums inženiera profesijā, kā arī atklāts viṇa devums Latvijas sporta vēsturē un statistikā, sasniegumi vieglatlētikā un to popularizēšana. Tas ir pirmais pētījums par inženiera, Triju Zvaigžñu ordeṇa virsnieka, Latvijas čempiona vieglatlētikā un sporta vēstures grāmatu autora, žurnālista A. Staǵa darbību un dzīvi. Pētījuma mērḳis ir atklāt A. Staǵa devumu un viṇa personības nozīmi Latvijai, izmantojot viṇa un autoru personīgos arhīvus, Latvijas Valsts arhīva dokumentus, Latvijas Nacionālās bibliotēkas krājumu.

Atslēgas vārdi: Andris Stağis, vieglatlētikas statistika, Rīgas Politehniskais institūts 